\title{
Сергій Долгоруков
}

провідний фахівець навчальної лабораторії авіаційних комп 'ютерноінтегрованих комплексів, кафедри АКІК, Наџіонального Авіачійного

Університету, м. Київ, Україна, е-таil: sdolgorukov@nau.edu.иа https://orcid.org/0000-0001-7690-0142

\section{АВТОМАТИЗОВАНЕ ОПТИМАЛЬНЕ ПРОЕКТУВАННЯ ВИПРОБУВАЛЬНИХ СТЕНДІВ НАВІГАЦЙНОГО ОБЛАДНАННЯ ЗА ДОПОМОГОЮ ШТУЧНОГО ІНТЕЛЕКТУ}

Анотація. Показано новий підхід для проектування випробувальних стендів навігаційного обладнання 3 використанням штучного інтелекту. Випробувальний стенд представляє собою складну мехатронну систему, що потребує одночасного оптимізування параметрів, що відносяться до різних дисциплін. Використання штучного інтелекту призначене для вирішення завдання координації прийняття оптимальних рішень в процесі проектування випробувального стенду. Ієрархічний підхід «від загального до детального» використовується для побудови моделі агентів на основі процесу проектування випробувального стенду. Цей підхід може бути використаний для проектування інших складних технічних систем.

Ключові слова: Випробувальний стенд навігаційного обладання, оптимізація та системний підхід, багатокритерійне прийняття проектних рішень

\section{Serhii Dolhorukov}

Leading specialist of the training laboratory of aviation computer-integrated complexes, Department of ACIC, National Aviation University, Kyiv, Ukraine,e-mail: sdolgorukov@nau.edu.ua https://orcid.org/0000-0001-7690-0142

\section{NAVIGATION EQUIPMENT TEST TABLE COMPUTER-AIDED DESIGN ARTIFICIAL INTELLIGENCE CONFIGURATION OPTIMIZATION}

Abstract. This paper proposes multi criteria decision making methodology to investigate the optimal configuration of navigation inertial unit dynamic test table. A new approach for designing navigation equipment test tables using artificial intelligence is described. A test table is a complex mechatronic system, which requires simultaneous optimization of parameters belonging to different disciplines. The use of artificial intelligence is implemented to solve the problem 
of coordinating optimal decision-making in the design process of the test bench. A top down hierarchical approach is used to build an agent model based on the test bench design process. This approach can be used to design other complex technical systems.

Keywords: Navigation equipment test table, System Optimization, Multi criteria decision making

Постановка проблеми. Процес розробки випробувальних стендів (BC), сумісний 3 вимогами четвертої промислової революції вимагає зміни як методів, так і систематичної процедури в процесі розробки.

Центральної мірою тут є інтегрована і синхронізована співпраця різних учасників виробничого процесу випробувальних стендів (механіка, електротехніка та електроніка, інформаційні технології) 3 самого початку розробки. Зростаюча технологічна складність і неоднорідність динамічних випробувальних стендів змушує приділяти більше уваги між-організаційному проектуванню в майбутніх процесах розробки такого обладнання.

Поведінку ВС повинно бути досліджено і оптимізовано не тільки на рівні окремих підсистем, на рівні ВС в цілому, а й на рівні взаємодії постачальників елементів всіх частин ВС - механіки, електротехніки / електроніки, інформаційних технологій. Це призводить до необхідності досліджувати і оптимізувати функціональну поведінку не тільки на рівні ВС, а й на рівні оточення загальної системи мережі компаній, що причетні до створення кінцевого продукту ВС та підтримки його життєвого циклу. Для цього необхідно проводити розрахунки 3 різними цілями i рівнями деталізації, які відповідно до поставленого завдання як конкретно висвітлюють окремі дисципліни (наприклад, електроніку), так і аналізують між-організаційні взаємодії між функціонально і просторово пов'язаними підсистемами в рамках різних дисциплін та постачальників відповідного обладнання. Застаріла модель проектування та виробництва, де апаратне забезпечення визначає структуру комплексу ВС навігаційного обладнання, функції пов'язані з апаратним забезпеченням, обмін інформації проходить від одного ієрархічного рівня до іншого, а ВС ізольований, повинна бути перетворена на:

- Гнучкий випробувальний комплекс навігаційного обладнання, де функції розподілені по мережі.

- Мережа проектування ВС може перетинати кордони компаній та виробничих організацій.

- Учасники процесу проектування ВС взаємодіють між ієрархічними рівнями.

- Bci учасники процесу проектування BC можуть обмінюватись інформацією один з одним.

- Випробувальний стенд є частиною мережі.

Аналіз останніх досліджень та публікацій. Штучний інтелект (ШІ) може допомогти вирішенню автоматизованих завдань у промислових 
процесах та налагодженню взаємодії між людьми або між постійно розширюваною спільною роботою команд людей, таким чином підвищивши ефективність. Декілька автономних підсистем за допомогою Ш можна об’єднати разом у одну загальну автономну систему більш високого порядку. Інтелектуальна технічна система характеризується здатністю зв'язуватися 3 іншою, гнучко координувати свої дії, постійно модифікуватися протягом свого життєвого циклу та демонструвати стійкість до зовнішніх втручань.

Автономні системи зустрічаються по всіх етапах промислових процесів: починаючи 3 аналізу вимог та закінчуючи проектуванням [1,2], закупівлями та управлінням поставками компонентів [3], диспетчеризацією [4, 5], виробництвом та виробничими процесами [6].

Весь процес проектування, а також необхідні підпроцеси можуть плануватися та обмінюватися даними 3 іншими задіяними процесами або 3 іншими автономними системами. У разі зміни робочих параметрів завдання динамічно переглядається та передається іншим учасникам процесу. Присутність людини необов'язкова. Мета такої системи - повна автоматизація проектування та виробництва, вимоги i критерії верифікуються та валідуються автоматично [6, 7, 8].

Мета статті: У разі проектування за допомогою Ш система, що навчена в процесі початкового навчання та разом 3 класичним запрограмованим програмним забезпеченням, отримує можливість виконати промисловий процес. Таким чином постає необхідність розробки автоматизованої системи проектування ВС 3 використанням Ш. Окреме питання стосується формулюванню вимог, що необхідні для навчання системи Ш процесу проектування ВС навігаційного обладнання. Таким чином у процесі проектування та виробництва ВС навігаційного обладнання Ш застосовується як технологічна процедура, створена для вдосконаленні процесів проектування, оптимізації динаміки руху випробувального стенду, його точності, та інших технічних характеристик $\mathrm{BC}$, та для автоматизації процесів проектування, заснованих на знаннях.

Виклад основного матеріалу. Проектування випробувальних стендів можна розглядати як класичне завдання оптимізації багатокритеріального мультидисциплінарного процесу, де задіяні експерти та САПР з механіки, електроніки та інформаційних технологій.

Для вирішення конфліктів у такому процесі проектування зазвичай використовуються методи TOPSIS, Viktor, Electra, Promethey [2, 4, 5]. Якщо багатокритеріальне завдання дозволяє звести його до більш простіших однокритеріальних формулювань, зазвичай використовуються генетичний алгоритм та інші природничі обчислювальні методи [2,9]. Також розповсюдженими є методи нечітких обчислень та іх похідні $[3,9,10]$.

Для повторюваних та стандартизованих виробничих процесів останнім часом використовуються різноманітні архітектури нейронних мереж, де основної проблемою є пошук оптимальних архітектур та навчання $[4,8]$.

Випробувальний стенд не належить до поширених виробів 
машинобудування, та зазвичай розробляється за індивідуальним замовленням.

Для вирішення завдання проектування ВC пропонується наступна процедура:

1. Метамоделювання процесів та моделей проектованих підсистем ВС.

2. Створення протоколу координації з використанням Ш.

Структуру трьох-осевого випробувального динамічного стенду наведено на рис.1. Випробувальний стенд складається 3: механічної частини, виконавчої частини, випробувального столу, системи керування та системи підтримки виконавчих підсистем стенду, робочого місця оператора, програмного середовища.

Стенд представляє собою керований кардановий підвіс, що містить блок управління приводними двигунами, керуючий пристрій системи управління та персональний комп’ютер (ПК). Керуючий пристрій на базі ПЛІС приймає сигнали датчиків на осях підвісу стенду та виробляє алгоритм управління двигунами

Випробувальний стенд складається 3:

-ККП - керований карданний підвіс;

•Д $\alpha$, Д $\beta$, Д $\gamma$ - двигуни осей тангажу, крену та курсу;

•ДК $\alpha$, ДК $\beta$, ДК $\gamma$ - датчики кутового положення осей тангажу, крену та курсу; П - платформа випробувального стенда;

•НО - навігаційне обладнання;

-КП - керуючий пристрій на базі ПЛІС;

-АГ, АФ, АУ - алгоритми генерування, формування та управління;

•БУД - блок управління двигунами,

•ПК - комп'ютер для обробки, зберігання та документування результатів випробувань та керування експериментом.

Керуючий пристрій на базі ПЛІС має структуру, описану нище:

- ПЛІС з кількістю програмованих логічних схем не менше 8000;

- Цифро-аналоговий інтерфейс, що містить АЦП і ЦАП 3 програмованою частотою дискретизації (розрядність не менше 16) для прийому сигналів з ланцюгів зворотного зв'язку БУД та датчиків кутів та для видачі сигналу на вхід суматора;

- паралельний портовий інтерфейс (розрядність не менше 16) для передачі дискретної інформації з датчиків кута, а також інтерфейс шини ПК і внутрішні шини зв'язку між окремими вузлами модуля керування.

Крім того, передбачається установка на кільце карданного підвісу термокамери 3 випробуваним приладом. ПК через КП формує закони зміни кутів тангажу $\alpha$, крену $\beta$, курсу $\gamma$ в часі, відповідно до експлуатаційних умов.

Цими законами можуть бути:

- синусоїдальна хитавиця 3 різними по осях тангажу, крену та 
курсу амплітудами, частотами та фазовими зміщеннями;

- випадкові процеси типу «білого шуму» із заданою матрицею спектральної густини;

- комбінований закон (для осі тангажа), що імітує кругове обертання із заданою кутовою швидкістю з накладенням коливань, гармонійних або випадкових.

У схемі керування забезпечується формування керуючих впливів на систему БУД, яка формує керуючі впливи для двигунів по всіх осях. Значення кутів $\alpha, \beta, \gamma$ виміряні відповідними датчиками кута ДК $\alpha$, ДК $\beta$, ДК $\gamma$, передаються через цифровий інтерфейс (RS-485) в КП на базі ПЛIC, який здійснює порівняння заданих значень кутів і вимірюваних на кожному такті управління. Сигнали різниці надходять на КП і далі на БУД для коригування відтворених законів руху по осях підвісу випробувального стенду. Інформація з навігаційного обладнання заводиться в ПК.

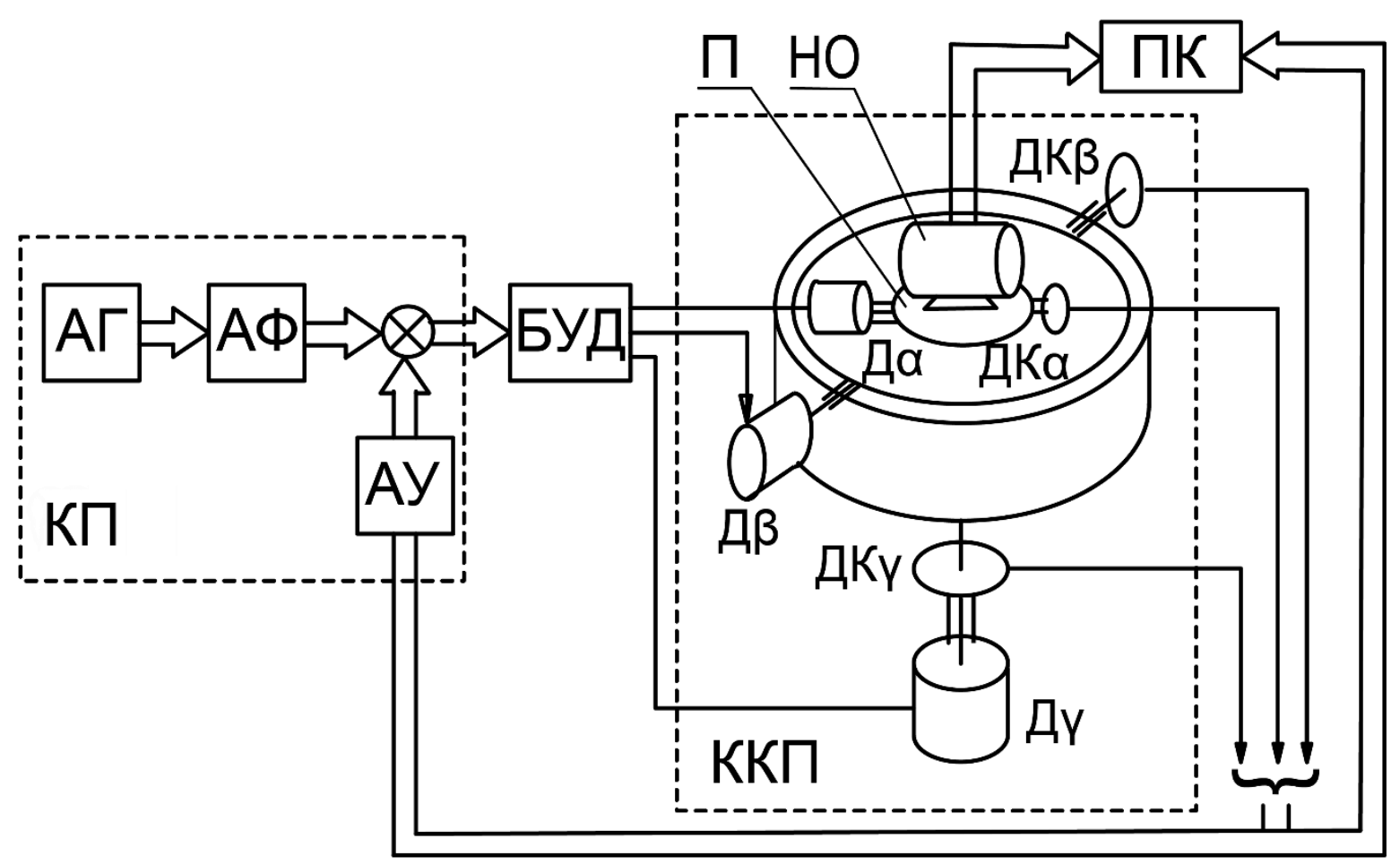

Рис 1. Функиіональні компоненти ВС навігаційного обладання

Стенд може бути віднесений до тривісних імітаційно-калібрувальних випробувальних стендів. Він може бути використаний для вирішення завдань калібрування вимірювачів кутових швидкостей за динамічними характеристиками та для випробувань всіх типів гіроскопічних приладів в умовах, що імітують роботу на платформі 3 хитавицею. Використання випробувального стенду в якості калібрувальної платформи для атестації датчиків кутових швидкостей за статичними характеристикам можливе тільки для датчиків середньої точності та грубих датчиків. Керуючий пристрій на базі ПЛІС (КП) генерує незалежні білі шуми, з яких блоком АФ 
за допомогою алгоритму формування генерується векторний випадковий процес із заданою матрицею спектральних густин. Блок АУ формує алгоритм управління двигуном, тобто стенд має замкнуту систему управління за кутовим положенням карданового підвісу. Кути за трьома осями карданового підвісу вимірюються датчиками ДК $\alpha$, ДК $\beta$, ДК $\gamma$. Випробувальний стенд, таким чином, імітує хитавицю по осях тангажу, крену та курсу. Завдання контурів позиційного регулювання полягає в тому, щоб якомога точніше і без затримки відстежувати переміщення окремих осей карданового підвісу відповідно до заданої траекторії динамічної хитавиці. Приводи по осях тангажу, крену та курсу використовуються для виконання необхідних рухів динамічних випробувань і для створення необхідних зусиль переміщення карданового підвісу. Елементи рами і основна опора разом утворюють механічну несучу конструкцію ВС. Її функція полягає в передачі механічних сил у обладнання, що випробовується. Для того, щоб в точці встановлення навігаційного обладнання зі статичними i динамічними силами навантаження, що виникають в результаті роботи системи, було якомога менше зсувів і відносних вібрацій, необхідна висока ступінь жорсткості і достатня амортизація конструкції ВС і приводів

Розглянемо окремі системи випробувального стенду більш детальніше.

1. Механічна частини складається 3 карданового підвісу та інших опорних конструкцій стенду.

2. Виконавчої частини складаєтся 3 електричних приводів, системи кодування положення, система передачі сигналу в обладнання для випробувань.

Загалом 3 опорними підшипниками це уворює підсистему механічної частини, що має приводити в рух кардановий підвіс разом с іншим обладанням.

3. Випробувальний стіл з термокамерою, або іншими приладами для додаткових умов випробування. Випробувальний стіл має бути спроектований для можливості встановлення та підключення до нього навігаційного обладнання та мати всі необхідні механічні, електричні та інші відповідні вузли.

4. Система керування та система підтримки виконавчих підсистем стенду (електричних, гідравлічних, пневматичних, тощо).

5. Робоче місце оператора для проведення випробувань

6. Програмне середовище проведення випробувань та середовище керування, моніторингу, перевірки, налаштування випробувального стенду.

Середовище має забезпечувати всі вимоги програми випробувань навігаційного обладнання та мати можливість калібрування та перевірки придатності випробувального стенду та відповідність стенду специфікаціям виробника - програма самодіагностики.

Вищезазначений перелік не $є$ вичерпним, його можна продовжити до декількох десятків разноманітних блоків, підсистем нижчого рівня, що складають комплекс випробувального стенду навігаційного обладнання. 
Завдання проектування на першому етапі починається з верхнього рівня підсистем та прямує на рівні підсистем, що підпорядковані за ієрархією.

В цьому дослідженні основна увага сконцентрована на двох верхніх рівнях p.1 та р.2. Інші підсистеми можуть бути спроектовані раніше ніж р.1 та p.2, однак такі обмеження накладають суттєві проблеми та унеможливлюють проектування оптимальних підсистем р.1 та р.2. Основні обмеження та параметри проектування р.3 використовуються як обмеження при проектуванні р.1 та р.2.

Рівень 4 проектується з використанням обмежень р.1 - p.3. Проектування оптимальної системи керування складає окреме комплексне завдання досліджень та виходить за межі цієї роботи.

Рівні проектування 5, 6 та інші підсистеми нижчого рівня мають проектуватись тільки 3 використанням параметрів обмежень р.1 - p.4. Оптимальне проектування програмного середовища для комплексу випробувального стенду навігаційного обладнання потребує окремих засобів, методології та інструментів дослідження, що не висвітлюються в даній роботі.

Різні підсистеми стенду, що використовуються для оцінки та аналізу під час проектування визначені в Таблиці 1.

Таблиияя 1

\section{Проектні рішення окремих підсистем завдання проектування}

стенду

\begin{tabular}{|c|c|c|c|}
\hline Підсистема & $\begin{array}{l}\text { Проектні } \\
\text { рішення }\end{array}$ & $\begin{array}{l}\text { Діапазон значень параметрів, } \\
\text { кількість варіантів }\end{array}$ & $\begin{array}{l}\text { Критерії для оцінки та } \\
\text { аналізу }\end{array}$ \\
\hline \multirow{3}{*}{$\begin{array}{l}\text { Карданна } \\
\text { конфігурація } \\
\text { i матеріали } \\
\text { виготовлення } \\
\text { стенду }\end{array}$} & $\begin{array}{l}\text { Матеріал } \\
\text { основи }\end{array}$ & Граніт, залізобетон & $\begin{array}{l}\text { Стабільність у часі, } \\
\text { вартість виробництва }\end{array}$ \\
\hline & $\begin{array}{l}\text { Матеріал } \\
\text { карданового } \\
\text { підвісу }\end{array}$ & Алюміній, композит & $\begin{array}{l}\text { Термічний опір, вимоги } \\
\text { до обертового моменту, } \\
\text { вартість виробництва, } \\
\text { час виходу на ринок, } \\
\text { найнижчий торсійний } \\
\text { резонанс }\end{array}$ \\
\hline & $\begin{array}{l}\text { Конфігурація } \\
\text { карданового } \\
\text { підвісу }\end{array}$ & Прямокутна, сферична & $\begin{array}{l}\text { Жорсткість перерізу, } \\
\text { стабільність розмірів, } \\
\text { складність інтерфейсу } \\
\text { корисного } \\
\text { навантаження, } \\
\text { складність досягнення } \\
\text { вимог та допусків } \\
\text { точності під час } \\
\text { виробництва, } \\
\text { вартість }\end{array}$ \\
\hline $\begin{array}{l}\text { Опорні } \\
\text { підшипники }\end{array}$ & $\begin{array}{l}\text { Тип } \\
\text { підшипників }\end{array}$ & $\begin{array}{lr}\text { Механічні шарикопідшипники, } \\
\text { гідростатичні } \\
\text { підшипники, } \\
\begin{array}{l}\text { повітряні підшипникия, магнітні } \\
\text { підшипники }\end{array}\end{array}$ & $\begin{array}{lr}\text { Хитавиця } & \text { (биття), } \\
\text { тертя, ортогональність } \\
\text { осей, } \\
\text { надійність, } \\
\text { зовнішнстісті } \\
\text { підтростота } \\
\text { пистеми, вартість }\end{array}$ \\
\hline
\end{tabular}




\begin{tabular}{|c|c|c|c|}
\hline $\begin{array}{l}\text { Система } \\
\text { кодування } \\
\text { положення }\end{array}$ & $\begin{array}{l}\text { Тип датчика } \\
\text { кутового } \\
\text { положення }\end{array}$ & $\begin{array}{l}\text { Iнерційні датчики, синусно- } \\
\text { косинусний } \\
\text { трансформатор } \\
\text { оптичні екодери, індуктосин }\end{array}$ & $\begin{array}{l}\text { Перешкодостійкість, } \\
\text { Точність, } \\
\text { Короткострокова } \\
\text { стабільність, похибка, } \\
\text { Вартість, } \\
\text { Складність. }\end{array}$ \\
\hline $\begin{array}{l}\text { Система } \\
\text { приводів }\end{array}$ & Тип приводу & 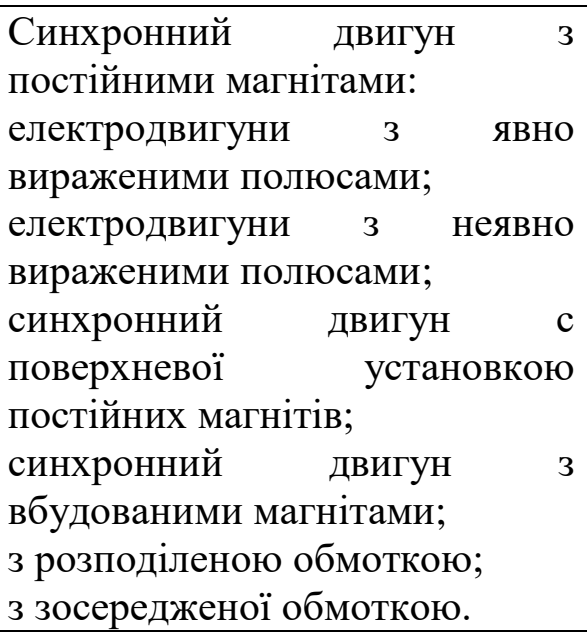 & 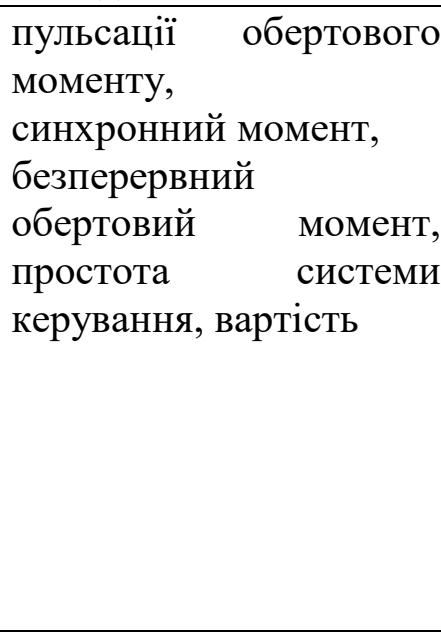 \\
\hline $\begin{array}{l}\text { Передача } \\
\text { сигналу в } \\
\text { обладнання } \\
\text { для } \\
\text { випробувань }\end{array}$ & $\begin{array}{l}\text { Тип передачі } \\
\text { сигналу }\end{array}$ & $\begin{array}{lr}\text { Провідний } & \text { обмежений, } \\
\text { провідний } & \text { необмежений, } \\
\text { беспровідний } & \end{array}$ & $\begin{array}{l}\text { Перешкодостійкість, } \\
\text { Вартість, } \\
\text { Складність. }\end{array}$ \\
\hline
\end{tabular}

Показані підсистеми, з якими пов'язана кожен проектний параметр, вибір проектного рішення, кількість доступних параметрів для проектного рішення та критерії для оцінки та аналізу.

Процедури розробки ВС, що використовуються на практиці в машинобудівній промисловості, можуть бути описані відповідно до загальної моделі процедур стандарту VDI 2206 [11,12]. При розробці ВС складна функціональна структура ВС приводить до виникнення безлічі завдань, що вимагають компетенцій 3 різних дисциплін. Як правило завдання механічного проектування, електричного проектування i проектування системи управління вирішуються відділами, які розділені за організацією процесів в дуже послідовному процесі розробки. 3 метою скорочення часу розробки, використовується процес одночасної і інтегрованої обробки всіх підзавдань i етапів 3 використанням методів спільної розробки. Розповсюджене використання стандартних компонентів, що поставляються ззовні, або повних функціональних вузлів, таких як поворотні столи чи системи керування приводами.

Процес проектування ВС складається с наступних етапів:

1. Розробка завдання на проектування:

- Визначення цільової вартості, експлуатаційних характеристик, робочих умов, завдань випробувань, ступені автоматизації.

2. Ескізне проектування

- Вибір типу динамічних випробувань

- Визначення типу ВС та кількості осей 
- Вибір типу і кількості пристосувань для встановлення навігаційного обладнання на ВС, пристосувань для підключення до системи обробки данних і необхідного додаткового обладнання

- Призначення рухів окремих компонентів ВС

- Визначення просторового положення осей переміщення

- Вибір датчиків зворотного зв'язку і приводів

3. Детальне проектування

- Вибір, визначення розмірів і просторового положення, що визначають конструкцію компонентів ВС: такі компоненти, як датчики, приводи, елементи для встановлення навігаційного обладнання

- З'єднання, що визначають конструкцію компонентів через компоненти карданного підвісу. Це компоненти, що залежать від форми елементів стенду.

- Вибір і визначення розмірів відповідних конструкцій рам карданного підвісу, функціонально-обумовлених отворів і детальних геометричних форм для компонентів карданного підвісу та несучої конструкції

4. Підготовка ВС до виробництва

- Геометрична деталізація у спеціалізованих САПР

- Доповнення виробничих специфікацій ВС

- Детальне визначення точної структури підсистем ВС

Приклад завдання для початку процесу проектування випробувального стенда наведено далі.

Стенд повинен виконувати завдання випробувань навігаційного обладнання:

1. Стенд повинен бути розрахований на випробування обладнання вагою $P$, яке займає обсяг $V$ і вимагає для підключення $N$ електричних з'єднань.

2. Стенд повинен забезпечувати максимальну точність випробувань, тобто його загальна сумарна похибка по всіх осях не повинна перевищувати $A$ кутових секунд вимог випробування обладнання для якого він проектується.

3. Стенд повинен обертати обладнання, що випробовується навколо взаємно перпендикулярних осей $Z$. Кількість осей $Z$ задається завданням випробувань обладнання, для якого він проектується. Відлік осей карданового підвісу стенду йде із зовнішнього осі до внутрішньої, зовнішня вісь лежить в горизонтальній площині.

Вихідні параметри проектування:

$$
\begin{aligned}
& P=50 \kappa 2 ; \\
& V=1 \mathcal{M}^{3}(1 \text { } \times 1 \text { м } \times 1 \mathrm{M}) ; \\
& N=12 ; \\
& A=50 ; \\
& Z=2 .
\end{aligned}
$$

Обмеження, що накладають вимоги до випробування того чи іншого виду навігаційного обладнання є основними для підготовки технічного завдання на проектування випробувального стенду.

Завдання проектування стенду полягає в тому, щоб в будь-яких умовах 
застосування виявити властивості випробувального комплексу, які забезпечували б його максимальну ефективність.

Формалізацію задачі оптимізації проектних параметрів випробувального стенду при методах проектування за допомогою САПР можна представити у вигляді:

$x_{i}=o p t ; i=l, \ldots, k ; C=\min ; M=\max ; A=\min ; T=\max ; R=\max$,

де $x_{i}, C, M, W, T, R$ - проектні параметри; вартість; маса випробуваного обладнання; граничні відхилення параметрів від заданих; довговічність; надійність.

На рис. 2 показано пропозицію системної моделі процесу розробки ВС навігаційного обладнання. Виходячи з розгляду ВС як мехатронної системи в цілому і використовуючи модель RAMI 4.0 [13], пропонується процедура структурованої обробки завдання проектування i виробництва ВС навігаційного обладнання, яка заснована на загальній системі проектування відповідно до директиви VDI 2206 [11,12] та IEC PAS 63088 [14].

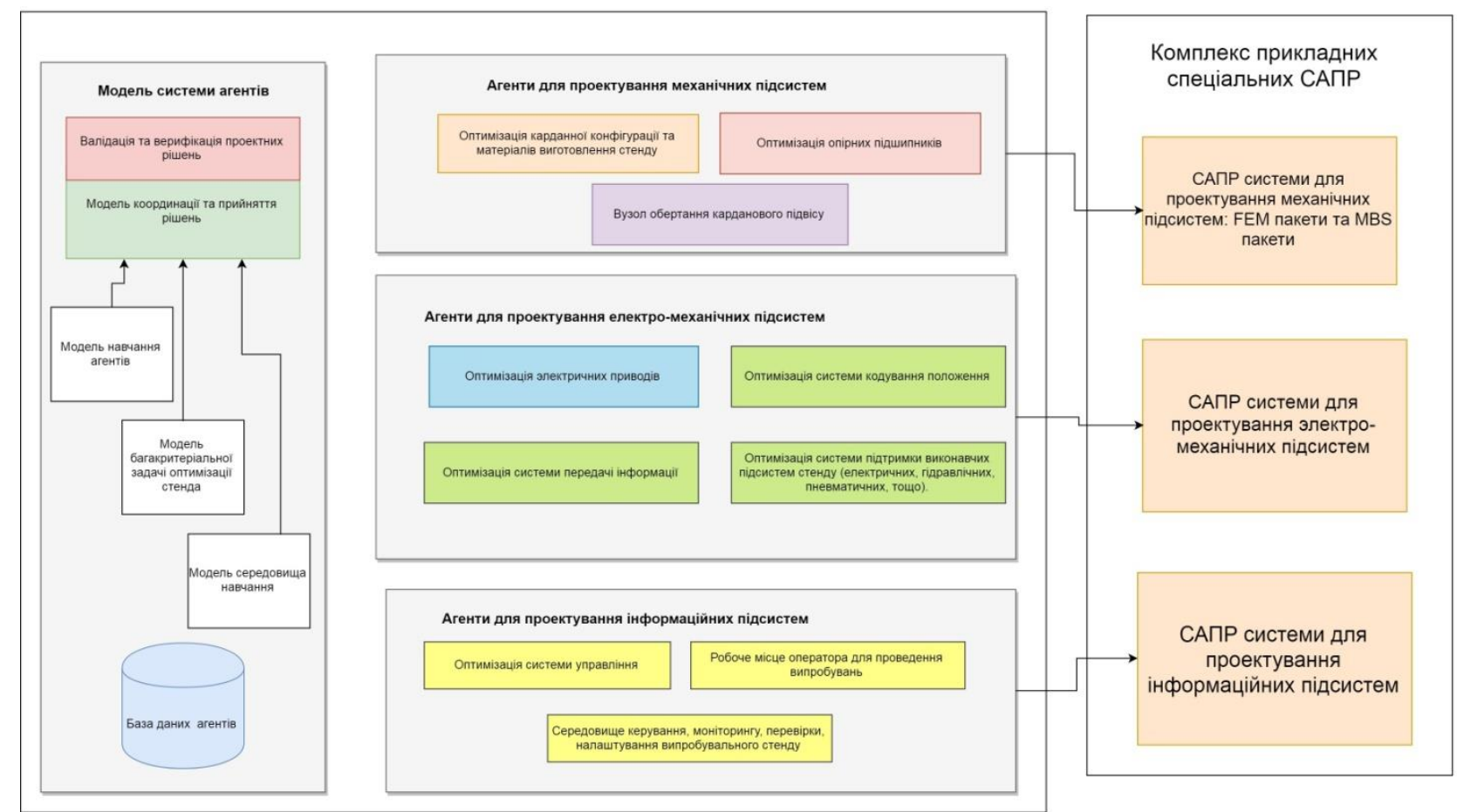

Puc. 2. Автономна система проектування ВС за домогою ШІ

Традиційні підходи для проектування оптимального випробувального стенду використовують аналітичні і стимуляційні методи. Однак ці підходи часто вимагають складних моделей з точним описом характеристик і функцій підсистем ВС. Інженерні розробки для цих систем часто є вирішальним аспектом, який обмежує реалізацію оптимальної системи випробувань навігаційного обладнання. 3 цих причин методи проектування без моделей $[7,8]$ та нові алгоритми штучного інтелекту розглядаються як доповнення існуючих методів.

Пропонована процедура розробки спрямована на забезпечення характеристик ВС на етапі розробки до такої міри, щоб можна було надійно 
забезпечити необхідні робочі характеристики і виключити функціональні дефекти.

Спочатку формулюється багатокритерійне завдання оптимізації ВС у вигляді спостережуваної марківської гри [15,16]. Потім на його основі створюється середовище навчання агентів, що моделює мережу гнучких проектних завдань з можливостями зміни і поліпшення підсистем ВС. Для створення моделі навчання агентів використовується декілька мультиагентних завдань з цілями, де різні агенти повинні не тільки навчитися оптимізувати свої параметри, але i координувати вивчені стратегії для досягнення парето-оптимального глобального рішення. Результатом навчання та побудови системи є те що агенти проектування підсистем ВС мають побудувати моделі координації, щоб поліпшити параметри всього випробувального стенду та виконати завдання на проектування. Заходи щодо модифікації, засновані на результатах, отриманих в ході введення в експлуатацію та випробувань реального прототипу $\mathrm{BC}$, повинні бути зведені до мінімуму і зводитися до тонкої настройки. Але навіть ці заходи можуть бути обмежені тільки змінами в програмному забезпеченні, як наприклад, параметризація контролера траекторії управління рухом, i більше не вимагають етапів проектних робіт. Випробування реального прототипу ВС додатково дозволяють оцінити результати розрахунків. У цьому контексті експериментальні випробування системи $\mathrm{i}$ компонентів розуміються як невід'ємні компоненти методології розробки, які необхідні в достатній мірі і без яких не можна повністю обійтися. Вони служать як для постійної валідації i, при необхідності, для поліпшення методів моделювання, так і для визначення інформації про параметри, яку неможливо визначити іншим способом.

Ця модель процесу може бути використана в якості методичної основи для розробки ВС з метою досягнення високої якості продукції при низькому ризику розробки. На наступному етапі деталізації завершується оптимізована Ш конструкція ВС і готується до виробництва. Потім процес завершується виробництвом і введенням в експлуатацію першого реального зразка ВС.

Висновки. Проектування спеціалізованих інтелектуальних САПР для ВС є складним завданням не тільки через зростання складності ВС та вимог проектування, але i через складний багато дисциплінарний процес його проектування. В даний час не існує загальноприйнятої методології для концептуального проектування мехатронних систем, а тим більше систем пректування ВС за допомогою Ш. Щоб підтримати процес проектування ВС ми розробили i представили новий підхід 3 використанням ШІ. Запропоновано введення інтелектуальних агентів для знаходження оптимального рішення інтелектуальних підсистем САПР, а також єдину модель багатокритеріальної задачі оптимізації ВС. Ця модель системи агентів дозволить усім учасникам процесу розробки ВС використовувати міждисциплінарні рішення під час оптимізації підсистем. Також представлено використання цього рішення в рамках проектування системи 
випробування навігаційного обладнання. Таким чином, показано багатокритерійний вибір рішень на основі вимог і функцій та системний підхід до проектування трьох-осевого випробувального динамічного стенду.

У нашій наступній науковій роботі ми збираємося докладно описати модель координації інтелектуальних агентів. Крім того, ми хочемо побудувати систему навчання агентів, що дозволяє вирішити завдання оптимізації параметрів випробувального стенду як завдання прийняття рішень в умовах невизначеності. Це дозволить різним агентам проектування підсистем стенду виявити різні стратегії координації, щоб поліпшити параметри всього випробувального стенду навігаційного обладнання.

\section{Jimepamypa:}

1. Biermann, D. (2014). "A framework for the computer-aided planning and optimisation of manufacturing processes for components with functional graded properties", in Proceedings of PPS-29: The 29th International Conference of the Polymer Processing Society - Conference Papers, vol. 1593, no. 1, pp. 762-765. doi:10.1063/1.4873887.

2. $\mathrm{Xu}$, Chuanbo, Yiming Ke, Yanbin Li, Han Chu, and Yunna Wu (2020). "Data-driven configuration optimization of an off-grid wind/PV/hydrogen system based on modified NSGA-II and CRITIC-TOPSIS" Energy conversion and management 215: 112892. doi: 10.1016/j.enconman.2020.112892.

3. Igoulalene, Idris \& Benyoucef, Lyes (2014). Consensus-Based Fuzzy TOPSIS Approach for Supply Chain Coordination: Application to Robot Selection Problem. IFAC Proceedings Volumes (IFAC-PapersOnline) 19. doi: 10.3182/20140824-6-ZA-1003.01916.

4. Goyal, Tanu \& Kaushal, Sakshi (2018). "Handover optimization scheme for LTEAdvance networks based on AHP-TOPSIS and Q-learning" Computer Communications 133, doi: 10.1016/j.comcom.2018.10.011.

5. T. Cardoso Bora, V. Cocco Mariani, L. dos Santos Coelho (2018). Multi-objective optimization of the environmental-economic dispatch with reinforcement learning based on non-dominated sorting genetic algorithm, Applied Thermal Engineering, doi: 10.1016/j.applthermaleng.2018.10.020

6. Gausemeier, Jürgen \& Rammig, Franz \& Schäfer, Wilhelm. (2014). Design Methodology for Intelligent Technical Systems: Develop Intelligent Technical Systems of the Future. doi: 10.1007/978-3-642-45435-6.

7. Raileanu, R., Denton, E., Szlam, A., and Fergus, R. (2018). "Modeling Others using Oneself in Multi-Agent Reinforcement Learning", arXiv e-prints, Retrieved from https://arxiv.org/pdf/1802.09640.pdf

8. Lee, D., He, N., Kamalaruban, P., and Cevher, V. (2020). "Optimization for Reinforcement Learning: From a single agent to cooperative agents", IEEE Signal Processing Magazine, vol. 37, no. 3, pp. 123-135. doi:10.1109/MSP.2020.2976000.

9. Rashid, Tabasam \& Beg, Ismat \& Husnine, S. (2014). Robot selection by using generalized interval-valued fuzzy numbers with TOPSIS. Applied Soft Computing. 21. 462-468. doi: 10.1016/j.asoc.2014.04.002.

10. Nasrollahi, M., Ramezani, J., \& Sadraei, M. A. (2020). FBWM-PROMETHEE approach for industrial robot selection. Heliyon, 6(5), e03859. doi: 10.1016/j.heliyon.2020.e03859.

11. Graessler, Iris and Hentze, Julian (2020). "The new V-Model of VDI 2206 and its validation" at - Automatisierungstechnik, vol. 68, no. 5, pp. 312-324. doi:10.1515/auto-20200015 .

12. STANDARD. VDI 2206:2004 - Design Methodology For Mechatronic Systems 
.Verlag des Vereins Deutscher Ingenieure (2004). Retrieved from: https://www.vdi.de/richtlinien/details/vdi-2206-design-methodology-for-mechatronic-systems

13. Alignment Report for Reference Architectural Model for Industrie 4.0. Intelligent Manufacturing System Architecture (2018). Retrieved from: https://www.plattformi40.de/PI40/Redaktion/DE/Downloads/Publikation/hm-2018-manufactoring.html.

14. TECHNICAL SPECIFICATION. IEC PAS 63088:2017 - Smart manufacturing Reference architecture model industry 4.0 (RAMI4.0) (2017). Retrieved from: https://webstore.iec.ch/publication/30082

15. Hacker, Kurt (2000). Comparison Of Design Methodologies In The Preliminary Design Of A Passenger Aircraft. doi:10.2514/6.1999-11.

16. Sellar, R. \& Batill, S.M. \& Renaud, J. (1996). Response Surface Based, Concurrent Subspace Optimization For Multidisciplinary System Design. doi:10.2514/6.1996-714.

\section{References:}

1. Biermann, D. (2014). "A framework for the computer-aided planning and optimisation of manufacturing processes for components with functional graded properties", in Proceedings of PPS-29: The 29th International Conference of the Polymer Processing Society - Conference Papers, vol. 1593, no. 1, pp. 762-765. doi:10.1063/1.4873887.

2. Xu, Chuanbo, Yiming Ke, Yanbin Li, Han Chu, and Yunna Wu (2020). "Data-driven configuration optimization of an off-grid wind/PV/hydrogen system based on modified NSGA-II and CRITIC-TOPSIS" Energy conversion and management 215: 112892. doi: 10.1016/j.enconman.2020.112892.

3. Igoulalene, Idris \& Benyoucef, Lyes (2014). Consensus-Based Fuzzy TOPSIS Approach for Supply Chain Coordination: Application to Robot Selection Problem. IFAC Proceedings Volumes (IFAC-PapersOnline) 19. doi: 10.3182/20140824-6-ZA-1003.01916.

4. Goyal, Tanu \& Kaushal, Sakshi (2018). "Handover optimization scheme for LTEAdvance networks based on AHP-TOPSIS and Q-learning" Computer Communications 133, doi: 10.1016/j.comcom.2018.10.011.

5. T. Cardoso Bora, V. Cocco Mariani, L. dos Santos Coelho (2018). Multi-objective optimization of the environmental-economic dispatch with reinforcement learning based on non-dominated sorting genetic algorithm, Applied Thermal Engineering, doi: 10.1016/j.applthermaleng.2018.10.020

6. Gausemeier, Jürgen \& Rammig, Franz \& Schäfer, Wilhelm. (2014). Design Methodology for Intelligent Technical Systems: Develop Intelligent Technical Systems of the Future. doi: 10.1007/978-3-642-45435-6.

7. Raileanu, R., Denton, E., Szlam, A., and Fergus, R. (2018). "Modeling Others using Oneself in Multi-Agent Reinforcement Learning", arXiv e-prints, Retrieved from https://arxiv.org/pdf/1802.09640.pdf

8. Lee, D., He, N., Kamalaruban, P., and Cevher, V. (2020). "Optimization for Reinforcement Learning: From a single agent to cooperative agents", IEEE Signal Processing Magazine, vol. 37, no. 3, pp. 123-135. doi:10.1109/MSP.2020.2976000.

9. Rashid, Tabasam \& Beg, Ismat \& Husnine, S. (2014). Robot selection by using generalized interval-valued fuzzy numbers with TOPSIS. Applied Soft Computing. 21. 462-468. doi: 10.1016/j.asoc.2014.04.002.

10. Nasrollahi, M., Ramezani, J., \& Sadraei, M. A. (2020). FBWM-PROMETHEE approach for industrial robot selection. Heliyon, 6(5), e03859. doi: 10.1016/j.heliyon.2020.e03859.

11. Graessler, Iris and Hentze, Julian (2020). "The new V-Model of VDI 2206 and its validation" at - Automatisierungstechnik, vol. 68, no. 5, pp. 312-324. doi:10.1515/auto-20200015 .

12. STANDARD. VDI 2206:2004 - Design Methodology For Mechatronic Systems. 
Verlag des Vereins Deutscher Ingenieure (2004). Retrieved from: https://www.vdi.de/richtlinien/details/vdi-2206-design-methodology-for-mechatronic-systems

13. Alignment Report for Reference Architectural Model for Industrie 4.0. Intelligent Manufacturing System Architecture (2018). Retrieved from: https://www.plattformi40.de/PI40/Redaktion/DE/Downloads/Publikation/hm-2018-manufactoring.html.

14. TECHNICAL SPECIFICATION. IEC PAS 63088:2017 - Smart manufacturing Reference architecture model industry 4.0 (RAMI4.0) (2017). Retrieved from: https://webstore.iec.ch/publication/30082

15. Hacker, Kurt (2000). Comparison Of Design Methodologies In The Preliminary Design Of A Passenger Aircraft. doi:10.2514/6.1999-11.

16. Sellar, R. \& Batill, S.M. \& Renaud, J. (1996). Response Surface Based, Concurrent Subspace Optimization For Multidisciplinary System Design. doi:10.2514/6.1996-714. 